Rok XVI (2021) | 2 (32) | S. 283-298

https://doi.org/10.12797/LV.16.2021.32.22

Licencja: CC BY-NC-ND 4.0

Rolandas Kregždys ๑

Lithuanian Culture Research Institute, Vilnius

rolandaskregzdys@gmail.com

\title{
ON THE ORIGIN OF POL. DIAL. KAUTEK 'DWARF', G DIAL. (EPR.) KAUTKE 'DITTO'
}

Keywords: Pol. dial. kautek, G dial. (EPr.) Kautke, etymology, mythologeme

Słowa klucze: pol. dial. kautek, niem. dial. (wschprus.) Kautke, etymologia, mitologem

\section{The characteristics of the Polish and Kashubian mythologeme dwarf}

It has been stated that the cult of dwarves was typical of West Slavs (see SD II: 470; also see Černý 1890: 20-35; Brückner 1902: 94-95, 1980: 208). It is also found in the area of East Slavs (see Šamâkìna 2008: 229). The belief in elves was widespread in the land of Kashubia. Furthermore, stories of dwarves can be found in Masuria, Kuyavia, Mazovia, Silesia and in the Western Poland, also in Bukovina - in the region, divided between Romania and Ukraine, which is located on the northern slopes of the central Eastern Carpathians, where a Polish diasporic community still exists (see KKLJ: 209; Kolberg XL: 60-68; also see Greń, Krasowska 2008: 7).

Lexemes in the shape of inherited words (I.1-12) and three types of borrowings (II.1-6 / III.1-2 / IV) are used to name these mythological beings:

(I) inherited Slavic forms -

(I.1) Pol. dial. (pl.) białeludzie / zimneludzie 'dwarves who cause adverse effects on human health' (Toeppen 1894: 29-30, 32);

(I.2) Pol. dial. (sg.) bożatko, bożątko, (pl.) bożęta, bodzieta 'a household deity, a dwarf; kindly spirits; dwarves' (SGP II3: 408, 409; Dźwigoł 2004: 13-14); 
(I.3) Kash. (masc., sg.) dremnè / (fem., sg.) dremnô 'a dwarf / a female dwarf' $\leftrightarrow$ (masc., sg.) dromnè / (fem., sg.) dromnå $\leftrightarrow$ (pl.) drebnê, drobne 'soulless, shortstatured human-shaped beings whose height is 1 feet; mortal creatures who extend the healthy lifespan to a thousand years; they use to act like humans: they dance, listen to music, get married, baptise their offspring, call each other by name; they wear red clothes and caps of the same colour; these little beings live in old graves, piles of stones, under the trees or in dough-troughs, in a stable or in a human house near the hearth; they use dishes made of gold and silver; dwarves have a king who wears a crown (see KKLJ: 103; SW I: 558; SEK II: 62, 64, 72; Dźwigoł 2004: 22);

(I.4) Pol. dial. garbusik 'a dwarf - an underworld guardian of treasures' (SKarł II: 54-55);

(I.5) MPol. (dial.) kołtek (see Hartknoch 1679: 141; Manlius 1719: 235; SWOKarl: 292), Pol. dial. kaltek'a dwarf; a fiery flying dragon (i.e. a brownie) who brings goods to some people' (see SW II: 413; SWil I: 460; SWOKarł: 292) $\leftrightarrow$ Pol. dial. kautek 'a dwarf in a red cap who reveals himself coming out from the soil or from the crib in the stable' (SGOWM III: 159; see subsection 2);

(I.6) Kash. (sg.) kråsńq 'a small human-shaped being who dwells under tree stumps (and especially under apple-trees or elder trees, etc.), under the floor, or behind the stove in a human house' $\leftrightarrow$ (pl.) kråsńąta (kraśnięta / krôsnjęta) 'dwarves who take care of horses, braid horse's mane' $\leftrightarrow$ (dim. sg.) kråsńotko 'a midget' $\leftrightarrow$ (pl.) krasńąči / krasńiči 'dwarves’ $\leftrightarrow$ (sg.) kråsńåk 'a dwarf' $\leftrightarrow$ (masc., sg.) kråsńik / (fem., sg.) †kråsńica 'ditto’ (see SGK II: 236-238; KKLJ: 103; also see Sychta 1957: 29; Kolberg XXXIX: 264);

Pol. dial. krasnoludek / krusnalek'a dwarfish man of a size of a fly or a bee who lives in a mousehole; a red round intestine worm which accesses to human body, potentially increasing his chances of becoming ill' (Moraczewski 1842: 509; Toeppen 1894: 28-29) ↔ krasnyludek, kraśnoludek / kraśnyludek 'a small human-shaped being who wears pointy red hat, dwells in the earth, in pits, ruins and all kinds of holes; helpful to humans when they are in need' $\leftrightarrow$ (sg.) krosnalek, (pl.) krosnalki 'a dwarf of a size of an insect who lives in a mousehole and gets out from there to spree in the night of the full moon; harmless to humans, but in the moment of fright it becomes a giant' (see Kolberg III: 104, XXXIX: 263; SW II: 530, 562);

(I.7) Kash. křąslåk 'a dwarf' (SGK II: 269; SKarł II: 494);

(I.8) Kash. kurpel 'a dwarf' (SGK II: 306; Dźwigoł 2004: 24)';

(I.9) Kash. †malëčk 'a dwarf' (SGK III: 42; Dźwigoł 2004: 22);

1 The origin of the mythologeme Kash. kurpel can evidently be related to Kash. kurdëpel 'a dwarfish man' (SGK II: 304), i.e. the absorption of the structural elements - dë- is reflected, cf. Kash. kur-dë-

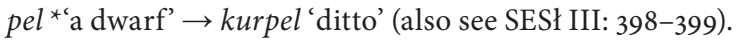


OPol. malylvdzye 'dwarves, i.e. daemone sparvuli, quos Poloni domos incolere credebant' (SStp IV: 153; SEBr: 497), Pol. dial. (pl.) małoludy 'dwarves' (Dźwigoł 2004: 22);

(I.10) Kash. omerečk 'a dwarf etc.' (SGK III: 320; Dźwigoł 2004: 11)²;

(I.11) Pol. dial. pasiecznik 'a dwarf who cares for bees' (Dźwigoł 2004: 12);

(I.12) Pol. dial. podziemek, podziomek 'a good-looking, small dwarf, helpful to humans, who lives underground' (see SKarł IV: 205; SW IV: 445; Dźwigoł 2004: 12);

(II) Germanisms -

(II.1) Pol. dial. chobołd, kołbuk (↔ Pol. dial. kołbóg, kołbug) etc., Pol. kobold, kobolt 'a mountain dwarf - a guardian of gems, crystals, and precious metals' < < G Kobold 'a household deity / mountain spirit; a dwarf etc.' (see Toeppen 1894: 20, 22-28, 30; KKLJ: 103; Kolberg XL: 54-58; also see SKarł II: 387; SW I: 287, II: 383, 408; DWG V: 1548-1552; Dźwigoł 2004: 25-26; Kluge 2011: 510);

(II.2) Pol. dial. cwerg, cwergiel 'a dwarf etc.' < G Zwerg 'a very small mythological being; a very powerful supernatural creature; a dwarfish man etc.' (see SGP IV³: 56o; also see Dźwigoł 2004: 25; Simek 1984: 475-477; Ström 1975: 170-171; DWG XVI: 1095-1099);

(II.3) Pol. (dial.) karzet 'a dwarf etc.', Pol. (dial./dim.; masc.) karlik, (fem.) karlica 'a very small supernatural being' etc. < MHG kleiner karl(e) 'a slim man' (see Dźwigoł 2004: 22-23; SESł II: 91; SEBor: 223-224; MLex I: 1520);

(II.4) OPol. (dial.) krzat 1466, (dial.) skrzat, skrzatek 1500 etc. 'dwarves, daemones parvuli, quos Poloni domos incolere credebant etc.' < EHG schrat 'a dwarf' (see SStp VIII: 259-260; SW VI: 184; Götze 1920: 194; also see Brückner 1980: 303; Dźwigoł 2004: 24-25; cf. SEBr: 497; SEBor: 554);

(I.5) Pol. skarbnik 'a dwarf - an underworld guardian of treasures' (SW VI: 132), Pol. dial. skarbownik 'a dwarf in a red hat - an underworld guardian of treasures in Czech' (SKarł V: 140) $\leftrightarrow(\mathrm{O} / \mathrm{M})$ Pol. skarb 'treasure, fortune; the Treasury' $\leftarrow$ OHG scarbôn, skarbôn 'to chase, to carve' $\leftrightarrow$ *'inscribed surface of a coin' (see SW VI: 131; SStp VIII: 216-217; Kluge 2011: 801; Kregždys 2016a: 576-577);

(II.6) Kash. (masc. sg.) ùndärërčk, (fem. sg.) ùndärërčka, (pl.) undererczki, underêrczkji 'dwarves' < G Untererdschchen, Unterirdschchen, LG Underer-

2 The origin of the lexeme has not been elucidated (see SEK III: 365 ). Therefore, the hypothesis can be put forward that Kash. omerečk 'a dwarf etc.' presupposes the remake of Kash. mora 'a nightmare, a spook who rides a horse to death, braids horse's mane, etc.' (SGK III: 102-106; Toeppen 1894: 36; SEK III: 256), as the Kashubians believed that mainly dwarves took care of horses. Kash. mora 'a nightmare' + suff. Kash. (n. deminutiva; masc.) -äčk / -ečk (see Lorentz 1925: 108) $\rightarrow$ *morečk 'a little nightmare $\rightarrow$ a dwarf' $\rightarrow$ (because of taboo) om-e-r-ečk 'a dwarf' (with metathesis of the root consonant ${ }^{*} m o$ - to $o m$ - and added parenthetic resp. non-etymological -e-). 
dschkes 'ditto' (for more details see KKLJ: 68, 103; Pohl 1943: 192, 286; Hinze 1965: 503-504; Dźwigoł 2004: 11; DWG XI: 1499);

(III) borrowings from Romance languages -

(III.1) Pol. dial. inkluz, ankluz 'a dwarf’3 (see Dźwigoł 2004: 16-17);

(III.2) Pol. dial. (pl.) petiki 'dwarves' (Greń, Krasowska 2008: 162) $\leftarrow$ Rm. pitic 'a dwarf' (Cioranescu 1966: 631-632);

(IV) Graecismes -

Pol. gnom 'a diminutive creature, a guard of terrestrial treasure' (SW I: 860; SWil I: 356) $\leftarrow$ G Gnom 'an haughty dwarf, a terrestrial spirit' ( $\leftrightarrow$ Fr. gnome /

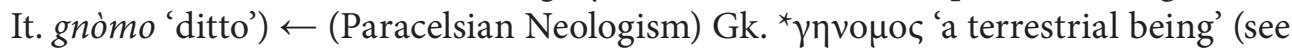
DWG IV': 651-655; Kluge 2011: 366; ESBM III: 99; Clédat 1914: 280; Pianigiani I: 625).

The Kashubians believed that dwarves were kindly beings: they used to play tricks, took care of animals (and especially of horses). These supernatural beings were generous to those who pleased them, e.g., they used to give gold or silver coins (or horse manure turned into gold) in return for donated milk or clothes. They could also move to malice if someone offended them or spied upon them (for more details see KKLJ: 68, 103-104, 208). People used to blame dwarves for most misfortunes (Toeppen 1894: 28).

The tradition of a dwarf and a dragon of treasure (i.e. brownie), who brings stolen goods to his master, is of German origin (see SD II: 470; Dźwigoł 2004: 10; Ivanova-Bučatskaâ 2006: 17; also see Brückner 1980: 208, 301-303) or, to quote Jonas Balys, "[...] whether the Germans themselves got it from Scandinavia and the British Islands" (JBR II: 317). Such an assumption can also be confirmed by the existence of a type of female dwarves, which presupposes the result of degradation of the old system of Western Germans' religion, i.e. goddesses OHG Holda $\leftrightarrow$ Holla ( $\leftrightarrow$ G Frau Holle), OHG Werra, MHG Bërhte, Stempe were demonised and, in the long run, they became related to wives of dwarves (for more details see Grimm 1844: 467; Wackernagel 1878: 138, 379; MLex I: 191, II: 1174; also see Kolberg VII: 205; Gimbutas 2001: 195; Goos 2019: 246).

The functions, ascribed to dwarves, e.g., taking care of horses, helping people (giving money, goods and services), are also of German origin (see Grimm 1844: 476-480; Kolberg VII: 246).

3 Jan Karłowicz (SWOKarł: 224) related the origin of the mythologeme with It. inclusa 'an appendage - something added or attached to an entity of greater importance or size' $\leftarrow$ adj. Lat. inclūsus 'closed; pent-up' (also see Pianigiani I: 864; ESUM II: 305). 


\section{The origin and peculiarities of the usage of the mythologemes Pol. dial. kautek, $G$ dial. (EPr.) Kautke}

The authors of the dictionary Słownik gwar Ostródzkiego, Warmii i Mazur (hereinafter SGOWM) did not indicate an area of the usage of the singular form of Pol. dial. kautek 'a dwarf' (SGOWM III: 159). Given the geographical range of SGOWM, prevalence of the form could be formally defined by the area of several subdialects of Warmia-Masuria Province in northeastern Poland ${ }^{4}$ :

(a) rural district of Ostróda city (G Osterode in Ostpreußen);

( $\beta$ ) Olsztyn Voivodeship (G Allenstein);

$(\gamma)$ rural district of Nidzica city (G Neidenburg).

Oskar Kolberg (XL: 67-68; also see SGOWM III: 145) presented the mythologeme in the plural form, i.e. Pol. dial. kautki 'dwarves in red caps who reveal themselves coming out from the soil or from the crib in the stable'. The lexeme was recorded in the North-Masurian subdialect of the Węgorzewo city (G Angerburg). The scholar was the first who decided to relate Pol. dial. kautki to G Waldleute 'woodmen resp. silvestres homines'. Due to the difference of the appearance $(\alpha)$, location $(\beta)$ and functions $(\gamma)$ of the mythonyms, such an attempt raises the following doubts:

$(\alpha-\beta)$ kautki are dwarfish men / dwarves of a few inches in height (resp. "kilkucalowe" (Kolberg XL: 67 ), i.e. 5-10 cm) who wear pointy red hats, dwell in the earth and stables $\neq$ Waldleute - foresters whose height is more than 1 cubit (resp. $45-56 \mathrm{~cm})$; they are shaggy and greyish, covered with moss; these supernatural beings live in the backwoods; they used to wear green clothes with red flaps and black tricorne hats;

( $\gamma$ ) kautki take care of horses, braid horse's mane $\neq$ Waldleute help women in the kitchen and do the laundry, they also participate in hunting and work together with millers ${ }^{6}$.

4 It should be noted that the mythologeme is not recorded in the Atlas of Masovia (AGM). It is also not mentioned in the Atlas Minor of Polish Dialects (MAGP I-XIII).

5 Cf. "[...] die als ein zusammen hausendes zwergartiges volk betrachtet werden, obgleich sie auch einzeln auftreten und dann zumal die weiblichen sich jenen höheren wesen anschliessen [...]" (Grimm 1844: 451); "Sie sind klein von gestalt, doch etwas grösser als elle, grau und ältlich, haarig und in moos gekleidet; oft werden blossholzweibel, seltener die männer genannt, diese sollen nicht so gutartig sein und tiefer in den wäldern wohnen, grüne kleider mit rothemaufschlag und dreieckige schwarze hüte tragen" (ibid.).

6 Cf. "zuweilen helfen sie den menschen in der küchenarbeit und beim waschen, äussern aber immer grosse furcht vor dem wilden jäger der sie verfolge" (ibid.: 452); "Waldmännchen, die in einer mühle dienste gethan und lange geholfen hatten, wurden dadurch verscheucht, dass ihnen die müllersleutekleider und schuhe hinlegten" (ibid. 453). 
The authors of SGOWM related the origin of the mytholegeme to G dial. Kautke, i.e. Pol. dial. kautek was attributed to Germanisms (see SGOWM III: 159; also see Dźwigoł 2004: 25). Such a decision was made on the basis of the information presented in the above-mentioned O. Kolberg's work.

Unfortunately, the decision of the compilers of the dictionary cannot be right because G dial. (EPr.) der Kautke 'a dwarf; a household deity / mountain spirit' is not an inherited German word, but a lexeme of West Slavic origin ${ }^{7}$. This statement is to be supported by the category of gender of the lexeme resp. by its masculine form, cf. der Kautke (see PrWb III: 168; also see Grannas 1943: 32). If the word was the inheritance of the Western Germans, the diminutive suffix G dial. $-\boldsymbol{k} \boldsymbol{e}(\leftrightarrow$ dim. suff. G -chen / LG -ken / -kin) (see Schröer II: 68; DM: 474; König 2004: 148, 186; Young, Gloning 2004: 126; Polenz 2009: 97, 124; Schümann 2010: 70-71; Elsen 2011: 81-83; Casemir, Fischer 2013: 90) should be obligatorily implied in the form of neuter (see Schümann 2010: 71; DM 391), cf. G dial. (EPr.) das Klênnutschke 'a dwarf' (see Fr I: 375), cf. also $\mathrm{G}$ der Matz 'a bird' $\rightarrow \mathrm{G}$ dial. das Mätzken = G das Mätzchen 'a little bird', G die Magd 'a girl' $\rightarrow$ das Mädchen 'a little girl $\rightarrow$ a girl' (also see Young, Gloning 2004: 258; Kluge 2011: 591, 608). Walther Ziesemer (1924) did not mention any example of a non-systemic gender change of the lexemes used in the East Prussian dialect.

Suff. G dial. - $k$ e was also used to form diminutives of $\boldsymbol{n}$. agentia type, cf. n. p. G Hartke $\leftarrow$ n. p. G Hartmut, Henneke $\leftarrow$ Hans (see König 2004: 124; also see Pott 1859: 157, 229). It should be noted that suff. G -chen / G dial. -ke also presuppose the connotation 'helpful to humans' of the words which belong to the same type of formation, i.e. n. agentia (see Schümann 2010: 71; DM 471).

7 Hence, the etymology of G dial. (EPr.) der Kautke which is specified further is impossible:

EHG kaute '(grave) pit; a grave; ground pit to store vegetables, fertilizers etc.; a clay pit; a moat; a bog etc.' (DW: 692; DWG V: 364-365; Götze 1920: 132; FHNDWe; also see Kluge 2011: 483), cf. -

(I) mythologeme G Donnerkaute 'Thunder's pit':

"[...] auf dem hessischen Knüllgebirge findet sich eine Donnerkaute [...]" (Grimm 1844: 155), i.e. [...] there is a Thunder's pit on the Knüllgebirge [i.e. Twisted Hill] in Hessen [...],

cf. also top. G Donnerkaute (see DWG II: 1239), that in East Prussia were believed to emerge a pit in the place where Thunder, in chase of a brownie, grasped the ground (see JBR I: 191);

(II) cf. the belief of the Kashubians, who took over the Germanic mythologeme dwarves, that these supernatural beings dwell in old graves and communicate with the dead (for more details see KKLJ: 103-104, 208)

+ dim. suff. G dial. $-\boldsymbol{k} \boldsymbol{e}$, which formally presupposes sememe ${ }^{\star ‘}$ a small grave $\rightarrow$ (antonomasia) grave spirit (resp. a shorty who lives in a grave (cf. Elsen 2011: 4, 81)) - a dwarf', cf. also G dial. (EPr.) Klênnutschke 'a dwarf' $\leftarrow$ G dial. (EPr.) Kleinnutsch 'bagatelle' (Fr I: 375).

The hypothesis can be supported by the belief of the Germans that "Die Bergmännchen weisen, ganz wie die Erdmännchen und Kobolde, auf Vorstellungen von Totengeistern hin [...]" (Vries I: 285), i.e. Mountain spirits, as well as dwarves and household deities, are identified with the spirits of the dead. 
The loan status or West Slavic character of G dial. (EPr.) Kautke is also presupposed by the change of suff. Pol. $\boldsymbol{e}$ to suff. G dial. $-\boldsymbol{k} \boldsymbol{e}^{8}$, i.e. Pol. dial. kautek 'a dwarf in a red cap who reveals itself coming out from the soil or from the crib in the stable' $\rightarrow$ G dial. (EPr.) Kautke 'a dwarf; a household deity / a mountain spirit' (see Scheme). The origin of Pol. dial. kautek 'a dwarf' can be justified by the statement of Franciszek Sławski (see SESł II: 375 ) that USrb. kottk' 'ditto' might have been ascribed to the derivatives of the suff. WSl. ${ }^{*}$-unz (n. agentis). Hence, it can be supposed that both mythologemes reflect absorption of the structural elements -un-:

WSl. dial. *kołtun 'a supernatural being' ( $\rightarrow$ USrb. koltun 'a tree demon' (SWOKarl: 292))

( $\leftrightarrow$ (M)Pol. (dial.) kottun 'a mat of hair (trichoma / plica incuborum); tangled hair; a tangle of branches; problem; townie; nickname; (pl.) a type of potatoes; rheumatism'

$<$ OUkr. ковтунъ 1584 ( $\rightarrow$ Ukr. ко́вту́н 'a mat of hair, wool or fur; skin disease (Plica polonica)' < PSl. ${ }^{*} k^{6}$ ltunz 'a mat of hair' (see SL II: 1053; SPXVI X: 492; SW II: 413-414; SKarł II: 409; SWil I: 512; Kucała 1957: 186; SEBr: 248; SESł II: 375-376; SEBor: 246; SEBań I: 763; SEMań: 86; SUM XVI-XVII st. XIV: 199; ESUM II: 487; ESBM IV: 311-312; ESSJ XIII: 191))

+ suff. -ek (n. deminutiva / n. qualitatis; n. actionis; n. agentis; n. instrumenti (for more details see Grzegorczykowa 1979: 6-7, 15, 22, 26, 33, 40, 43, 45, 53-54; GWJPM: $397,400,408,420,426,444))$

$\rightarrow$ MPol. ${ }^{\star} k o t t u n e k$, Pol. dial. ${ }^{*} k a t t u n e k$ / USrb. ${ }^{*} k o l t u n e k$ 'a small mat of hair; a dwarf' ${ }^{\prime 10}$

$\rightarrow$ (with an absorption of -un-) $)^{11}$ MPol. kottek 'a mat of hair; earring' (SPXVI X: 491; SW II: 413) $\leftrightarrow$ MPol. (dial.) kottek, Pol. dial. kattek 'a dwarf; an igneous brownie which brings treasure', USrb. kottk 'a dwarf'

$\rightarrow$ Pol. dial. kautek'a dwarf' with the root structural element -au-, which is of identical etymological value with Pol. dial. -at- (due the vocalization of the lateral consonant $\ell$ ) (for more details see Dejna 1973: 114-115; Schaarschmidt 1997: 142; see also Kregždys 2016b: 61, 2020: 104).

8 Cf. G dial. Poschundek 'order' $\leftarrow$ Pol. porzadek 'ditto', G dial. Roschke 'croissant, roll' $\leftarrow$ Pol. rożek 'ditto' etc. (for more details see Nyenhuis 2013: 150-153).

9 The lexeme was attributed to Germanisms by Renata Dźwigoł (2004: 25). The researcher rejected the Slavic origin of the word presented by Franciszek Sławski (see SESł II: 375) and interpreted it as it were a shortened form of USrb. koboltk.

10 Cf. also Pol. dial. kołtunnik 'a herb used to cure plica; ground-ivy (Glechoma hederacea)' (SKarł II: 409).

11 Cf. variation of the Germanism Pol. frasunek 'concern, care' $\leftrightarrow$ MPol. fras 'ditto' (SW I: 773; SPXVI VII: 123). 
The semantic shift of the mythologeme kautek (i.e. 'a dwarf' $\leftarrow$ 'a supernatural being' $\leftarrow$ 'a mat of hair') was predetermined by antonomasia (i.e. mythological subject $\leftarrow$ an object with unsacred connotation - see Scheme), cf. the origin of the West Slavic mythologeme willow 'a devil' $\leftarrow$ 'a dwelling of devil' $\leftarrow$ 'willow tree' (see SD I: 335), as it was thought that the dwarves used to felt mats of human hair:

"Sie sind die kleinen Wesen, die in Maßuren den Menschen das Haar verwirren, so daß man einen solchen Koltki, wie man das verwirrte Haar selbst dann auch wieder nennt, schwer entwirren kann. Es muß abgeschnitten warden" (Pohl 1943: 286), i.e. The Masurian little creatures used to felt a mat of human hair to make Koltki, which can hardly be disentangled and must be cut off. The word Koltki is also used to name tangled hair.

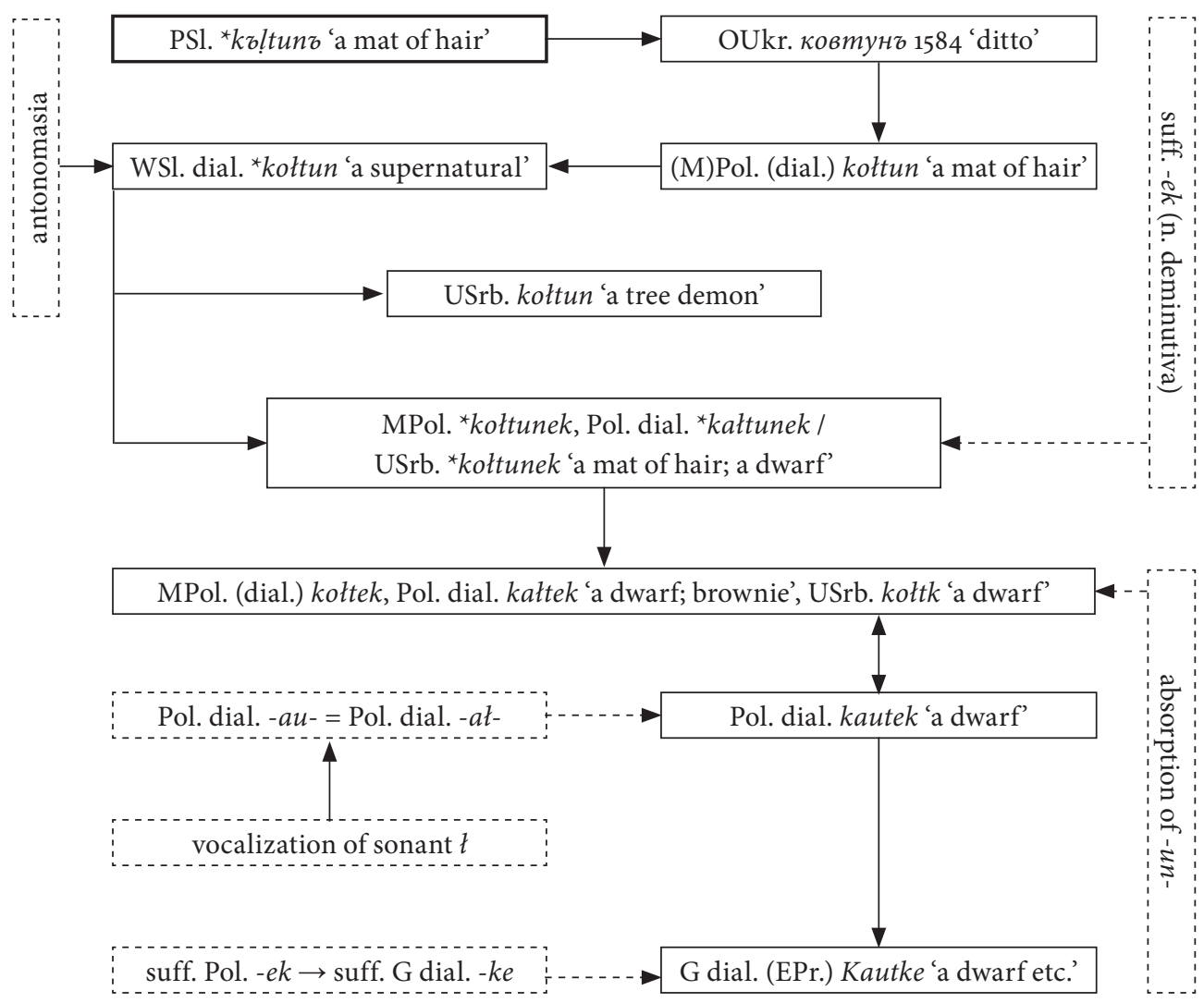

Scheme. The sequence of the origin of Pol. dial. kautek, G dial. (EPr.) Kautke

Unfortunately, in the latest works on the formation of words in the Prussian language, Pol. dial. kautek was interpreted as a cognate of OPr. cawx 'a devil' E 11 (see Biolik 2009: 59). It was evidently for that reason that some researchers attributed the mythonym Pol. dial. kautek to the layer of the lexis of the Baltic origin (see Nepo- 
kupnyj 1976: 137; PrWb III: 168; Laučûte 1982: 47; Kiseliūnaitė, Kukure 2011: 193), but they did not specify the relationship between the above-mentioned mythologeme and the borrowing G dial. (EPr.) der Kautke'a dwarf; a household deity / a mountain spirit'. It should be underlined that they did not present an etymological description of the structural element $-t$-, absent in OPr. cawx.

It is true that Anatoly Nepokupny (1976: 137) tried to solve the issue with the help of the diminutive Lith. kaukutis 'a soul of an unbaptised child' (LKŽe). Unfortunately, the explanation is fallacious. This statement would be really acceptable if Lith. kaukutis was an inherited word of the East Balts, but the root kauk- is a loan from the West Baltic area (see Smoczyński 1989: 309; also see Kregždys 2020: 81). The above-mentioned diminutive is a late derivate which started to be used only in Lithuanian $^{12}$.

Moreover, the inherited West Germanic onyms (toponyms and proper names) of the identical morphological structure and semantic value presuppose the new status of OPr. cawx, i.e. a borrowing - a Germanism, but not an old inheritance, cf.:

$\left(a_{1}\right)$ top. EHG / G Kauxdorf'the country's capital city in the region of Brandenburg in Germany - some $112 \mathrm{~km}$ South of Berlin ${ }^{13}$ ' (NTSGW II: 318) with the variant of top. MHG Kuckuckdorf 1217 'cuckoo's / devil's village' ${ }^{14}$, the latter may be related to MHG / EHG kukuk 'cuckoo; devil; a fool' (see MLex I: 1765-1766; DWG V: 2521-2529; also see DW: 722; Kluge 2011: 546);

$\left(\alpha_{2}\right)$ p. n. EHG Andreas Kauxdorf 1522 (Lingke 1769: 133; Beuche 2012: 27), EHG Daniel Kauxdorf 1524, 1569, 1575, Daniel Kauxendorf 1524 (Brüggemann, Brunken 1991: 1463) presupposed by top. EHG Kauxdorf;

( $\beta$ ) G dial. Kaukengähl 'saffron (Crocus); turmeric (Curcumae Longae Rhizoma)' (Reichling 2012: 203) most probably is related to G dial. ${ }^{\star}$ kauken (pl.) $\leftrightarrow \mathrm{G}$ dial. (EPr.) Kauken 'dwarves' (Pohl 1943: 286).

12 Latvian mythologeme Kuhkitis 'a dwarf' has been recorded only in Kārlis Kristiāns Ulmanis' dictionary (see Ulmann 1872: 124). Later the same form was included in Kārlis Mülenbachs' dictionary, i.e. Latv. kūkintis 'ditto' (ME II: 333). The mythonym was not recorded in the old writings and dialectal dictionaries. It is evidently for that reason it should be attributed to the group of learned words, i.e. to neologisms. Moreover, it should be noted that some researchers interpreted the lexeme as an old inheritance (see Kiseliūnaite, Kukure 2011: 187-188). The statement is fallacious because if the mythonym was an inherited word, palatalized consonant Latv. $-k$ - (before $-\bar{i}-$ ) would be changed to affricate $-c$ - (see Endzelins 1951: 184-185). The absence of the abovementioned phonological change presupposes Latv. kükitis to be attributed to borrowings from Lithuanian (see Endzelynas 1957: 40-41), cf. Slavonicism Lith. dial. kùkas 'a devil' (LKŽe) $\leftarrow$ MPol. $k u k$ 'an evil spirit, a devil' (SPXVI XI: 540), Kash. kuka 'an evil spirit etc.' (SGK II: 289; SEK III: 113-114) either from Russian, cf. Ru. dial. кýка 'a wood spirit which dwells in a bath' (SRNG XVI: 30) or Bel. dial. кýкa 'an imaginary evil spirit used to frighten children' (ESBM V: 149). The highlanders' dialect is used in this region (see Schönfeld 1991: 182-183). See https://www.uebigau-wahrenbrueck.de/verzeichnis/objekt.php?mandat=18675. 
In the disclosure of the properties of the origin of top. EHG / G Kauxdorf, the hypothesis presented by Wojciech Smoczyński (1989: 309) is to be used, i.e. the place name is to be compared with MHG helle-gouch 'a devil' (MLex I: 1234). However, changed morphological structure of the first component of the toponym is to be explained on the basis of the partial contamination between the lexemes of Western Germans, but not of Western Balts:

MHG der gouch (sg.) / die gäuch (pl.) 'a cuckoo; bastard; a fool' (see MLex I: 10571058; also see Kluge 335)

$\leftrightarrow$ (partial contamination) ${ }^{15}$ MHG / EHG $\boldsymbol{k} u k u \boldsymbol{k}$ 'a cuckoo; a devil; a fool'

$\rightarrow \mathrm{MHG}^{\star}{ }^{\star} \boldsymbol{k a u x}$ 'a cuckoo, a devil'.

Hence, the conclusion can be drawn that OPr. cawx presupposes a Germanism, but not an inherited mythologeme of Western Balts:

OPr. cawx 'a devil'

$\leftarrow \mathrm{MHG}^{\star} k a u x$ 'a cuckoo, a devil'.

In summary, it can be stated that the alternation of undoubtedly West Germanic toponyms EHG / G Kauxdorf ↔ top. MHG Kuckuckdorf 1217 'devil's / cuckoo's village' ${ }^{16}$ presupposes the same etiological model (i.e. Germanic origin) of the place names which, contrary to what was common to do in the past, are to be attributed to the group of Germanisms, but not to inherited onyms of Western Balts, cf. top. OPr. Kaukelawke 1394, Kaukenynen 1400, Kawkowagen 1314 // top. OPr. Chucunbrasth 1254, Cucenbrast 1254, Kuke 1251, Cukemedie 1419 (Gerullis 1922: 58, 75; see also Kregždys 2012: 150). It is to be assumed that these toponyms reflect the referent 'cuckoo / -'s $\leftrightarrow$ devil / -l's place'. Therefore, all attempts to reconstruct apophonic morphological archetypes of the West Baltic origin are essentially fallacious, cf. OPr. ${ }^{\star} k a u k a s \leftrightarrow$ OPr. ${ }^{\star} k \bar{u} k s$ or OPr. ${ }^{\star} k u k a s$ 'a familiar' (cf. Schall 1966: 20-21; PEŽ II: 295-296; SEK III: 114).

\section{Conclusions}

1. Pol. dial. kautek 'a dwarf' presupposes a derivative composed of WSl. dial. *kołtun 'supernatural being' (> USrb. kołtun 'a tree demon' $\leftrightarrow(\mathrm{M}) \mathrm{Pol}$. (dial.) kołtun 'a mat of hair etc.') and dim. suff. -ek, i.e. Pol. dial. ${ }^{\star} k a t t u n e k$ 'a small supernatural being who felts a mat of human hair $\leftrightarrow$ a dwarf' is to be reconstructed.

15 Cf. an alternation of verb G dial. kaukeln $\leftrightarrow$ gaukeln 'to play with fire' (see Schröer II: 68).

16 Cf. place names of the Hannover district, i.e. top. G Kuckuckshorn 'devil's horn', Kuckucks-Mühle 'devil's mill' (see Müller 1825: 104). 
2. G dial. (EPr.) der Kautke 'a dwarf; a household deity / mountain spirit' should be attributed to the loanwords from the Polish language reflecting the change of the suff. Pol. dial. - ek to suff. G dial. - $k e$.

3. OPr. cawx 'a devil' E 11 is not related to the origin of Pol. dial. kautek 'a dwarf'.

\section{Abbreviations}

Bel. - Belarusian; EHG - Early New High German; EPr. - East Prussian (a combination of Early High New German and Middle Low German); Fr. - French; G - German (New High German); Gk. - Greek; It. - Italian; Kash. - Kashubian; Lat. - Latin; Latv. - Latvian; LG Low German; Lith. - Lithuanian; MHG - Middle High German; MPol. - Middle Polish; OPol. - Old Polish; OPr. - Old Prussian; OUkr. - Old Ukrainian; Pol. - Polish; PSl. - ProtoSlavic; Rm. - Romanian; Ru. - Russian; Ukr. - Ukrainian; USrb. - Upper Sorbian; WSl. West Slavic (proto)form

\section{Abbreviations of Grammatical Terms, etc.}

adj. - adjective; dial. - dialectal form; dim. - diminutive; E - Elbing Vocabulary; pl. - plural; p. n. - personal name; sg. - singular; suff. - suffix; top. - toponym

\section{Symbols}

${ }^{*}$ reconstructed form

$<$ developed from reconstructed form

$\leftarrow$ developed from an existing form

$\leftrightarrow$ lexical interference

F semantic discrepancy

\section{Literature}

AGM: H. Horodyska-Gadkowska, A. Strzyżewska-Zaremba, A. Kowalska, Atlas gwar mazowieckich, vol. 1-10, Wrocław - Gdańsk - Kraków 1971-1992.

Beuche W., 2012, Die Persönlichkeiten von Eilenburg in ihrer über 1ooojährigen Geschichte, Norderstedt.

Biolıк M., 2009, [rec.] Mikkels Klussis, Słownik odbudowanego języka pruskiego. Bazowy słownik prusko-polsko-pruski dla dalszego odrodzenia leksyki (dialekt sambijski), Kowno 2007, Litewski światowy ośrodek nauki, kulturyi oświaty, s. 478, "Język Polski” LXXXXIX, pp. 57-60.

BRÜCKNER A., 1902, Literatura religijna w Polsce średniowiecznej, vol. 1: Kazania i pieśni, Warszawa. 
BRÜCKNER A., 1980, Mitologia słowiańska i polska, Warszawa.

BrügGemann T., Brunken O., 1991, Handbuch zur Kinder- und Jugendliteratur. Von 1570 bis 1750, Stuttgart, https://doi.org/10.1007/978-3-476-03237-9.

Casemir K., Fischer CH., 2013, Deutsch. Die Geschichte unserer Sprache, Darmstadt.

Cior anescu A., 1966, Diccionario etimologico rumano, Tenerife.

Clédat L., 1914, Dictionnaire Étymologique de la Langue Française, Paris.

ČERnÝ A., 1890, Mythiske bytosće łužiskich Serbow, "Časopis Maćicy Serbskeje” 43, pp. 3-50.

Dejna K., 1973, Dialekty polskie, Wrocław - Gdańsk.

DM: E. Hentschel, P.M. Vogel (eds), Deutsche Morphologie, Berlin - New York 2009, https:// doi.org/10.1515/9783110212617.

DW: L. Diefenbach, E. Wülcker, Hoch- und nieder-deutsches Wörterbuch der mittleren und neueren Zeit, Basel 1885.

DWG I-XVI: Deutsches Wörterbuch von Jacob und Wilhelm Grimm, vol. 1-16, Leipzig 18541961 (Quellenverzeichnis - 1971).

DźwigoŁ R., 2004, Polskie ludowe słownictwo mitologiczne, Kraków.

Elsen H., 2011, Grundzüge der Morphologie des Deutschen, Berlin - Boston, https://doi. org/10.1515/9783110237900.

ENDZELĪNs J., 1951, Latviešu valodas gramatika, Rīga.

ENDZELYNAS J., 1957, Baltų kalbų garsai ir formos, Vilnius.

ESBM I-XIV: V.U. Martynaǔ, G.A. Cyhun (eds), Etymalagičny sloǔnik belaruskaj movy, vol. 1-14, Minsk 1978-2017.

ESSJ I-XLI: O.N. Trubačev, A.F. Žuravlev, Etimologičeskij slovar' slavânskih âzykov, vol. 1-41, Moskva 1974-2018.

ESUM I-VI: O.S. Mel'ničuk, Etimologičnij slovnik ukrä̈nskoï movi, vol. 1-6, Kiiv 1982-2012.

FHNDWE: O. Reichmann (ed.), Frühneuhochdeutsches Wörterbuch 1-11, Berlin - New York 1986-2016, [on-line:] https://fwb-online.de/.

FR I-II: H. Frischbier, Preussisches Wörterbuch. Ost- und Westpreussische Provinzialismen in alphabetischer Folge, vol. 1-2, Berlin 1882-1883.

Gerullis G., 1922, Die altpreußischen Ortsnamen, Berlin - Leipzig.

Gimbutas M., 2001, The Living Goddesses, Berkeley - London.

Goos G., 2019, Goddess Holle, Norderstedt.

Göтzе A., 1920, Frühneuhochdeutsches Glossar. Zweite, stark vermehrte Auflage, Bonn.

Grannas G., 1943, Plattdeutfche Volksmärchen aus Oftpreußen, Königsberg (Pr.).

Greń Z., Krasowska H., 2008, Słownik górali polskich na Bukowinie, Warszawa.

Grimm J., 1844, Deutsche Mythologie, $2^{\text {nd }}$ edition, Göttingen.

GrZegorCZyKowa R., 1979, Zarys słowotwórstwa polskiego. Słowotwórstwo opisowe, Warszawa.

GWJPM: R. Grzegorczykowa, R. Laskowski, H. Wróbel (eds), Gramatyka współczesnego języka polskiego. Morfologia, Warszawa 1999.

Hartкnoch Ch.J., 1679, Selectoe dissertationes historica de variis rebus Prussicis, Francofurti - Lipsiae - Jenae.

Hinze F., 1965, Wörterbuch und Lautlehre der deutschen Lehnwörter im Pomoranischen (Kaschubischen), Berlin.

Ivanova-BuČAtskaÂ Û.V., 2006, Plattes Land: Simvoly Severnoj Germanii (slavânogermanskij etnokul'turnyj sintez v meždureč'e El'by i Odera), Sankt-Peterburg.

JBR I-V: J. Balys, Raštai, vol. 1-5, Vilnius 1998-2004. 
Kiseliūnaitė D., Kukure K., 2011, Pruski cawx, litewski kaukas, kuroński kauks - rozwój mitonimu od pierwszych wzmianek do czasów teraźniejszych, "Pruthenia" 6, pp. 185-201.

KKLJ: F. Lorentz, A. Fischer, T. Lehr-Spławiński, Kaszubi. Kultura ludowa i język, Toruń 1934.

KLUGE F., 2011, Etymologisches Wörterbuch der deutschen Sprache, $25^{\text {th }}$ edition, Berlin - Boston, https://doi.org/10.1515/9783110223651.

Kolberg I-LXXXIV: O. Kolberg, Dzieła wszystkie, vol. 1-84, Warszawa - Kraków Wrocław - Poznań 1857-2002.

KöNIg W., 2004, Atlas Deutsche Sprache. Mit 155 Abbildungsseiten in Farbe, Berlin.

KREGŽDYs R., 2012, Baltų mitologemų etimologijos žodynas I: Kristburgo sutartis, Vilnius.

KREGŽDYs R., 2016a, Lietuvių kalbos polonizmų žodynas / Słownik polonizmów w języku litewskim, Vilnius.

KREGŽDYs R., 2016b, Lietuvių kalbos polonizmų žodyno specifikacija / Charakterystyka słownika polonizmów w języku litewskim, Vilnius.

KregžDys R., 2020, Baltų mitologemų etimologijos žodynas II: Sūduvių knygelè, Vilnius.

KucAŁA M., 1957, Porównawczy słownik trzech wsi małopolskich, Wrocław.

LAUČÛTE Û., 1982, Slovar' baltizmov v slavânskih âzykah, Leningrad.

Lingke J.T., 1769, D. Martin Luthers merkwüdige Reifegefchichte, zu Ergäzungfeiner Lebensumftäde..., Leipzig.

LKŽE: Lietuvių kalbos žodynas (t. I-XX, 1941-2002), electronic version, Vilnius 2013.

LoREnTz F., 1925, Geschichte der pomoranischen (kaschubischen) Sprache, Berlin - Leipzig, https://doi.org/10.1515/9783111727950.

MAGP: Mały atlas gwar polskich, Pracownia Dialektologiczna (Pracownia Atlasu i Słownika Gwar Polskich from vol. 4) Zakładu Językoznawstwa PAN, Cracow, vol. I-II, ed. in chief K. Nitsch, vol. III-XIII, ed. in chief M. Karaś, Wrocław - Kraków 1957-1970.

Manlius CH., 1719, Scriptores rerum Lusaticarum..., Lipfiæ - Budiffæ.

ME I-IV: J. Endzelīns (ed.), K. Mülenbacha Latviešu valodas vārdnīca, vol. 1-4, Rīga $1923-1932$.

MLex I-III: M. Lexer, Mittelhochdeutsches Handwörterbuch, vol. 1-3, Leipzig 1872-1878.

MoraczewsKi J., 1842, Starożytności polskie ku wygodzie czytelnika porzadkiem abecadłowym zebrane, vol. 1, Poznań.

Müller W., 1825, Alphabetisch-statistisches Verzeichniss der bewohnten Ortschaften des Königreichs Hannover. Mit der Angabe der Art und Gröfse und der Entfernung derselben von der Land-Drostey, von dem Amte oder Gerichte, von der Steuer-Receptur, von der Pfarre und von der Post-Station. Als Zugabe zu der neuen Ausgabe der Karte des Königreichs Hannover in 20 Bogen, Hannover.

Nepokupny A.P., 1976, Balto-severnoslavânskie âzykovye svâzi, Kiev.

NTSGW I-VI: A.A. Mützell (ed.), Neues topographisch-statistisch-geographisches Wörterbuch des Preussischen Staats, vol. 1-6, Halle 1821-1825.

Nyenhuis A., 2013, Polnische - $k$-Suffixe in den deutschen Dialekten, "Acta Universitatis Wratislaviensis. Studia Linguistica" 32, pp. 147-163.

PEŽ I-IV: V. Mažiulis, Prūsų kalbos etimologijos žodynas, vol. 1-4, Vilnius 1988-1997.

Pianigiani I-II: O. Pianigiani, Vocabolario etimologico della lingua Italiana, vol. 1-2, Roma - Milano 1907.

Poнl E., 1943, Die Volkssagen Ostpreußens, Königsberg (Pr.). 
Polenz P., 2009, Geschichte der deutschen Sprache, $10^{\text {th }}$ edition, completely revised, Berlin New York, https://doi.org/10.1515/9783110215526.

Ротт A.F., 1859, Die Personennamen, insbesondere die Familiennamen und ihre Entstehungsarten: auch unter Berücksihtigung der Ortsnamen, Leipzig.

PrWв I-VI: E. Riemann, U. Tolksdorf, R. Goltz (eds), Preußisches Wörterbuch. Deutsche Mundarten Ost- und Westpreußens, vol. 1-6, Neumünster 1981-2005.

Reichling J., 2012, Arends Volkstümliche Namen der Drogen, Heilkräuter, Arzneimittel und Chemikalien, $19^{\text {th }}$ edition, revised and expanded, Berlin - Heidelberg.

SchaARschmidt G., 1997, A Historical Phonology of the Upper and Lower Sorbian Languages, Heidelberg.

SCHAll H., 1966, Baltische Gewässernamen im Flußsystem „Obere Havel“ (Südost-Mecklenburg), "Baltistica" 2 (1), pp. 7-42, https://doi.org/10.15388/baltistica.2.1.2.

Schönfeld H., 1991, Die niederdeutsche Sprache in den Ländern Sachsen-Anhalt und Brandenburg, "Niederdeutsches Jahrbuch" 114, pp. 175-201.

SchröER I-II: K.J. Schröer, Beitrag zu einem Wörterbuche der deutschen Mundarten des ungrischen Berglandes, vol. 1-2, Wien 1858.

Schümann M., 2010, Diminutiv, Diminutivum, [in:] E. Hentschel (ed.), Deutsche Grammatik, Berlin - New York, pp. 70-71.

SD I-V: N.I. Tolstoj (ed.), Slavânskie drevnosti. Etnolingvističeskij slovar', vol. 1-5, Moskva 1995-2012.

SEBAŃ: A. Bańkowski, Etymologiczny słownik języka polskiego, vol. 1-2, Warszawa 2000.

SEBor: W. Boryś, Słownik etymologiczny języka polskiego, Kraków 2005.

SEBR: A. Brückner, Słownik etymologiczny języka polskiego, Warszawa 1970 [1927].

SEK I-VI: W. Boryś, H. Popowska-Taborska, Słownik etymologiczny kaszubszczyzny, vol. 1-6, Warszawa 1994-2010.

SEMań: W. Mańczak, Polski słownik etymologiczny, Kraków 2017

SESŁ: F. Sławski, Słownik etymologiczny języka polskiego, vol. I-V, Kraków 1952-1982.

SGK I-VII: B. Sychta, Słownik gwar kaszubskich na tle kultury ludowej, vol. 1-7, Wrocław $1967-1976$.

SGOWM I-VII: Słownik gwar Ostródzkiego, Warmii i Mazur, vol. I-III, ed. Z. Stamirowska, vol. IV-V, eds H. Perzowa, D. Kołodziejczykowa, vol. VI, eds D. Kołodziejczykowa, K. Sobolewska, vol. VII, ed. K. Sobolewska, Wrocław - Warszawa - Kraków - Gdańsk 1987 (vol. I), Wrocław - Warszawa - Kraków 1991 (vol. II), Warszawa - Kraków 1993-2018 (vol. III-VII).

SGP: Słownik gwar polskich, ed. M. Karaś (Źródła, vol. 1), J. Reichan (vol. 2-9, nr 2), S. Urbańczyk (vol. 2-5), J. Okoniowa (vol. 6-9, nr 2), B. Grabka (vol. 7-9, nr 2), R. Kucharzyk (vol. 9, nr 2-vol. 10, nr 2), vol. 1-3: Wrocław - Warszawa - Kraków 1977-1991, vol. 4-10: Kraków 1992-2019.

SimeK R., 1984, Lexikon der germanischen Mythologie, Stuttgart.

SKARŁ: J. Karłowicz, Słownik gwar polskich, vol. I-VI (vol. IV-VI prepared to print by J. Łoś), Kraków 1900-1911.

SL: S.B. Linde, Słownik języka polskiego, vol. I-VI, $2^{\text {nd }}$ edition, revised, Lwów 1854-1860.

SMOcZYŃsKi W., 1989, Über einige bedenkliche baltisch-slawische Ansätze, "Indogermanische Forschungen" 94, pp. 306-327, https://doi.org/10.1515/if-1989-0120.

SPXVI I-XXXVIII: Słownik polszczyzny XVI wieku, vol. 1-38, Wrocław - Kraków - Warszawa 1966-2020. 
SRNG I-LI: Slovar' russkih narodnyh govorov, vol. 1-51, Leningrad (Sankt Peterburg) 1965-2019.

SStP: S. Urbańczyk (ed.), Słownik staropolski, vol. I-XI, Wrocław - Warszawa - Kraków 1953-2002.

Sтröм Ä.V., 1975, Germanische Religion, [in:] idem, H. Biezais, Germanische und baltische Religion, "Die Religionen der Menschheit”, vol. 19, 1, Stuttgart - Mainz, pp. 11-306.

SUM XVI-XVII sT. I-XVII: Slovnik ukraïns'koï movi XVI - peršoï polovini XVII st., vol. 1-17, L'viv 1994-2017.

SW: J. Karłowicz, A.A. Kryński, W. Niedźwiedzki (eds), Słownik języka polskiego, vol. I-VIII, Warszawa 1900-1927.

SWIL: A. Zdanowicz et al., Słownik języka polskiego, vol. I-II, Wilno 1861.

SWOKARє: J. Karłowicz, Słownik wyrazów obcego a mniej jasnego pochodzenia używanych w języku polskim, vol. 1-3, Kraków 1894-1905.

SychтA B., 1957, Kaszubskie nazwy diabła (wyjątki ze Słownika kaszubskiego), "Język Polski” XXXVI, pp. 28-44.

ŠAMÂkìna T.I., 2008, Mifalogiâ i belaruskaâ litaratura, Mìnsk.

Toeppen M.P., 1894, Wierzenia mazurskie z dodatkiem, zawierającym klechdy i baśnie Ma$z u r o ́ w, 2^{\text {nd }}$ edition, expanded, Warszawa.

Ulmann C.CH., 1872, Lettifches Wörterbuch. Erfter Theil. Lettifch=deutfches Wörterbuch, Riga.

VRIES I-II: J. de Vries, Altgermanische Religionsgeschichte, vol. 1-2, Berlin - Leipzig 1935-1937.

WACKeRnAGEL W., 1878, Altdeutsches Handwörterbuch, Basel.

Young Ch., Gloning T., 2004, A History of the German Language Through Texts, London New York, https://doi.org/10.4324/9780203488072.

Ziesemer W., 1924, Die ostpreußischen Mundarten, Königsberg.

\section{On the Origin of Mythonyms (Pol. dial. kautek, (G dial) (wschprus.) Kautke) Abstract}

Referring to etymological analysis, the author of this article presents a new hypothesis concerning the origin of the Polish mythological name kautek and the East Prussian word Kautke. The analysis refers to the description of derivatives and semantic development of those mythonyms. While summing up the research results, one may conclude that mythological names such as Pol. dial. kautek, G dial. (EPr.) Kautke belong to lexemes of the West Slavic origin. More precisely, those mythonyms are derived from Pol. dial. *kattunek 'a mythological being who makes human hair tangled' $\leftrightarrow$ 'a dwarf' WSl. *kottun 'a mythological being' (> USrb. kottun 'wił - a demon living in a tree’ $\leftrightarrow(\mathrm{M})$ Pol. (dial.) kołtun 'hair allegedly tangled because of a disease called trichoma' $<$ PSl. ${ }^{*} k^{*} l$ tunz 'curled hair') + dem. suff. Pol. -ek.

East Prussian mythologeme Kautke belongs to Polonisms used in the past in the Duchy of Prussia. 


\section{0 pochodzeniu mitonimów pol. dial. kautek, niem. dial. (wschprus.) Kautke Abstrakt}

W niniejszym artykule, poprzez odwołanie do analizy etymologicznej, została zaproponowana nowa hipoteza o pochodzeniu polskiej nazwy mitologicznej kautek oraz wschodniopruskiego Kautke. Przedstawiona analiza dotyczy opisu derywacji i rozwoju semantycznego tych mitonimów. Podsumowując wyniki badań, można stwierdzić, że nazwy mitologiczne pol. dial. kautek, niem. dial. (wschprus.) Kautke należą do leksemów pochodzenia zachodniosłowiańskiego. Dokładniej rzecz ujmując:

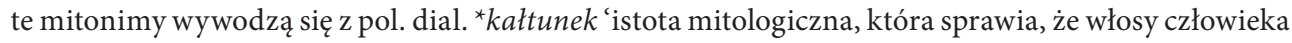

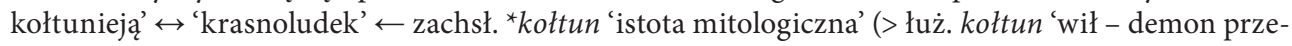
mieszkujący w drzewie' $\leftrightarrow$ (śr.)p. (dial. kołtun 'włosy skręcone rzekomo wskutek choroby trichoma' < $<$ psł. ${ }^{*} k^{z}$ ltunz 'skręcone włosy') + dem. suff. p. $-e k$.

Mitologem wschodniopruski Kautke należy do polonizmów, dawniej używanych na terenie Prus Książęcych. 